\title{
Influences on adolescent food choice
}

\author{
BY RICHARD SHEPHERD AND CATHERINE M. DENNISON \\ Institute of Food Research, Earley Gate, Whiteknights Road, Reading RG6 6BZ
}

\section{Influences sur le choix des aliments chez l'adolescent}

\begin{abstract}
RÉSUMÉ
Pendant l'adolescence, une bonne alimentation est essentielle pour supporter des taux de croissance plus élevés, et, d'autre part, les habitudes diététiques apprises dans l'enfance et l'adolescence peuvent, dans une certaine mesure, être conservées dans la vie d'adulte. L'adolescence est une période de modifications physiologiques et psychologiques. Un processus de transition vers une plus grande autonomie des parents commence, et les pairs deviennent de plus en plus le centre de référence dans bien des domaines de la vie de l'adolescent. Une forme d'expression de la recherche de l'adolescent de s'établir comme un membre autonome de la société se révèle dans une modification des habitudes alimentaires.

Les études sur la nutrition des adolescents ont révélé des prises élevées de lipides, des prises peu importantes de fibres et de micronutrients, et des modes d'alimentation caractérisés par des repas sautés, l'usage de la restauration rapide et le 'grignotage'. Beaucoup d'adolescents, plus particulièrement les filles, essaient de perdre du poids en régulant leurs prises alimentaires. Les études ont trouvé que de 5-30\% des adolescentes suivent un régime à un moment ou à un autre. Le régime de suppression (mesure de l'importance avec laquelle les gens réduisent leur consommation afin de stabiliser ou de réduire leur poids) est plus élevé chez les filles que chez les garçons, et ceci est vrai aussi bien chez les adultes que chez les adolescents. Les résultats chez les filles dès l'âge de 9 ans sont aussi élevés que chez la femme adulte.

On connaît relativement peu de choses sur les facteurs qui affectent le choix des aliments par les adolescents. Le régime de n'importe quel individu, qu'il soit enfant, adulte ou adolescent, est le résultat de l'imbrication de toute une variété de facteurs, dont beaucoup sont complexes et conflictuels. Le goût apparaît comme un déterminant primaire du choix chez l'adolescent, les soucis de coût et de santé étant secondaires. Il n'est pas bien prouvé que les connaissances en matière de nutrition jouent un rôle important. On a trouvé que les parents avaient une influence significative sur l'alimentation de leur enfant, mais que ses pairs deviennent de plus en plus importants quand il avance en âge. L'alimentation de l'adolescent est une cible très importante pour l'investissement des producteurs et des traiteurs qui ciblent leurs produits, leurs lieux de restauration et leur publicité spécifiquement sur ce secteur de la population. Pour n'en citer qu'un, les publicités présentent une image du monde et de ce qui est disponible; avec d'autres médias, avec les connaissances personnelles et les interactions sociales, elles agissent comme une source d'information sur les normes sociales, culturelles et sub-culturelles.

La majorité des études sur les influences sur les choix alimentaires des adolescents ont utilisé des approches non structurées, mais un travail récent a utilisé l'application de la
\end{abstract}


théorie psychologique sociale hautement structurée du comportement planifié. Dans une étude, 675 adolescents ont été pris dans huit établissements scolaires (quatre mixtes, et quatre non mixtes) de différentes régions d'Angleterre, comprenant des filles et des garçons, âgés soit de 11-12 ans, soit de 14-15 ans. Les attitudes et le contrôle perçu étaient les composantes du modèle que l'on a trouvé être à l'origine de la plus grande variance dans les intentions de manger des frites et des friandises. Le fait d'ajouter une nouvelle mesure, celle du comportement des amis, augmentait la prédiction d'intention. Les filles se déclaraient plus soucieuses de leur santé, avaient des croyances et des attitudes plus positives à l'égard des fruits, et des croyances et des attitudes plus négatives à l'égard des frites et des friandises. Les différences entre garçons et filles étaient plus marquées dans le groupe des plus âgés que dans celui des plus jeunes. Les effets du contexte socio-économique et du type d'établissement scolaire étaient minimes. Une seconde étude ( $n$ 96) a largement reproduit ces résultats, montrant que cette mesure était stable avec le temps, et liant l'intention directement au comportement mesuré.

Il est nécessaire de comprendre le comportement alimentaire des adolescents si l'on veut améliorer les habitudes alimentaires. L'application d'approches structurées à des attitudes modèles offrent un moyen de comprende les rôles joués par les différents facteurs. La 'pression' des pairs et le degré de contrôle que les adolescents sentent qu'ils ont sur les choix qui sont faits sont des facteurs importants.

There is strong concern amongst parents, the medical profession, educators and, to an extent, government regarding the quality of teenagers' diets. Frequent media headlines have reflected these concerns. Although we are far from having a comprehensive view of the eating habits of this age-group, the studies that have been performed suggest that the adolescent diet is generally poor, lacking in essential nutrients, high in fat, salt and sugar.

There are several reasons why it is important to understand the factors that influence the dietary choices of young people. Good nutrition is essential during adolescence in order to support the increased rates of growth that characterize puberty and the teenage years. A poor diet has, in addition, been shown to contribute directly to the development of many illnesses and disorders, amongst them coronary heart disease, a condition that is responsible for one of the highest numbers of fatalities in Western society, and some cancers. Research has shown that a number of the precursors of these conditions are to be found in children and teenagers (for example Stare \& Dwyer, 1969). It has also been established that the dietary habits that emerge during this period remain, at least in part, as the individual progresses into adulthood (Birch, 1987); hence, the diets of tomorrow's adults are being determined by the choices young people are making today. Thus, it is argued that since adult dietary habits are extremely resistant to change (Prättälä, 1989), the optimum time to target intervention is when these habits are being formed, in childhood and adolescence.

Few attempts at influencing adolescent diets have been based on any real understanding of the factors that affect young people's food choice decisions. Indeed, little research has examined the factors having influence. Following a consideration of adolescence as a developmental period, the present paper aims to integrate findings regarding the adolescent diet and detail some of the attempts made to try to understand what is influencing the dietary choices of this age-group. 


\section{THE NATURE OF ADOLESCENCE}

Adolescence has been shown to be a significant period in the development of dietary habits. It is a developmental period during which the individual experiences severe physiological and psychological changes (Simmons et al. 1987). Although the notions of this time as being characterized by 'storm and stress', where 'generation gaps' open up and 'identity crises" ensue are now widely disputed (Jackson \& Bosma, 1992), the period necessitates major adaptation and adjustment (Coleman \& Hendry, 1990). There are major changes in the nature of relationships with family and friends. A process of transition towards greater autonomy from parents begins (Noller \& Callan, 1991) and peers become increasingly central to many areas of the adolescent's life with greater significance being accorded their role as companions, providers of advice and feedback and as models for behaviour (Jackson, 1993). Peer groups may become important determinants of an adolescent's interests and values; values that may contrast radically with those of parents and school (Coleman \& Hendry, 1990).

One expression of an adolescent's search to establish himself or herself as an autonomous member of society is through a change in eating habits. Teenagers become increasingly in control of what, where and when they eat, consuming an increasing proportion of their total food intake outside the home (Truswell \& Darnton-Hill, 1981). Adolescence is, in addition, a time of inc:eased awareness of the body, its shape and size, most especially for females (Davis \& Furnham, 1986). Thinness is seen as the desirable body shape for women in Western cultures and, thus, many adolescent females, and increasing numbers of adolescent males, strive to achieve this goal by means of dietary restraint. As a consequence of these potential influences the teenage years may be a period of potential nutritional vulnerability.

\section{ADOLESCENT NUTRITION}

Surveys of adolescent nutrition have revealed a number of consistent features. Levels of energy intake have been shown to be above recommended daily amounts (Department of Health, 1989), although the amount of energy that is derived from fats is of concern (Department of Health, 1989; Crawley, 1993); the two major contributors to fat intake in the Department of Health (1989) study were milk and chips. Adamson et al. (1992) found that the average 11-12 year old consumes three portions of crisps, six cans of soft drink, seven bars of chocolate or other biscuits and seven puddings every week. Intake of fibre and micronutrients in adolescent populations has repeatedly been found to be low.

It is not only the total nutrient intake of adolescents which is of concern, their patterns of eating are also of significance. The adolescent diet is characterized by missed meals, unconventional meals, fast food, and frequent 'snacking' (Greenwood \& Richardson, 1979; Truswell \& Darnton-Hill, 1981; Bull, 1985; Rolls, 1988). A common observation is that teenagers tend to eat more often than the traditional norm of three meals daily (Hampton et al. 1967; Huenemann et al. 1968; Nelson, 1982). Recent market research has suggested that $5 \%$ of the nation's children have nothing to eat in the morning before they leave for school (a figure that rises considerably when teenage girls are considered in isolation), and that $21 \%$ do not come home to a hot meal in the evening (The Gardner Merchant School Meals Survey; Gardner Merchant Ltd, unpublished results). Contradictory evidence exists as to the effect of snacking on teenage nutrition (Huenemann et al. 1968; Greger et al. 1979; Post et al. 1986; Bigler-Doughten \& Jenkins, 1987). 
Thomas \& Call (1973) have questioned the place which such foods occupy in the teenage diet, since foods eaten between meals appeared to provide a relatively good balance of nutrients. It must be noted, however, that what constitutes a 'snack' greatly varies between studies (Truswell \& Darnton-Hill, 1981).

A recurring theme in discussion of childhood and adolescent nutrition is the role played by school meals. Traditionally the school lunch has been an important source of energy and nutrients for young people. Initially provided by charitable organizations in an attempt to combat malnutrition and its negative effects on classroom performance, the form of school meals has changed greatly since their introduction at the turn of the century. Until 1980, local authorities had the responsibility to provide a school meal, of an established nutritional standard, for every child who wanted one. Until the 1980s about two-thirds of the school population took a school meal, with about $8 \%$ of these being provided free of charge (Rose \& Falconer, 1992). The 1980 Education Act, however, abolished nutritional standards and price controls, the minimum obligations of education authorities being significantly relaxed. Since 1988 it has been compulsory for local education authorities to put the school meals out to competitive tendering with there being an increasing trend towards putting the responsibility for provision on individual schools. This has resulted in huge variations in the cost, menu, quality and nutritional content of the meal provided from area-to-area, and indeed from school-toschool. In the majority of secondary schools cash cafeterias have been introduced where young people have free choice from a wide range of foods.

Estimates of current levels of provision suggest that nationally the school lunch system feeds approximately $42 \%$ of all school pupils (Nutritional guidelines for school meals; The Caroline Walker Trust, unpublished results). Other pupils buy food outside the school, return home or bring a meal prepared at home into the school. Demographic and economic factors have been found to have a significant influence on uptake of school lunch, with those most likely to have a school lunch being younger (Roberton, 1981) and from the higher social classes (Golding et al. 1984). Within the current system, the nutritional quality of school dinners provided is dependent on the local authority setting guidelines or even the individual caterer. However, in many instances the school pupils can exercise freedom of choice and, hence, the type of foods and diets chosen and consumed is dependent on the individual pupils. Thus, in order to make any changes to the types of foods consumed in these settings, we need to understand the reasons for dietary choices of adolescents.

\section{FACTORS INFLUENCING FOOD CHOICE IN ADOLESCENTS}

The diet of any individual, whether child, adult or adolescent, is the result of the intermeshing of a range of factors, many of which are complex and conflicting. Various attempts have been made to develop models that address what factors influence food choice (Yudkin, 1956; Pilgrim, 1957; Khan, 1981; Randall \& Sanjur, 1981; Krondl \& Lau, 1982; Shepherd, 1985; Booth \& Shepherd, 1988). These models incorporate a whole range of factors relating to the characteristics of the individual (e.g. age, sex, educational level, beliefs and mood), specifics relating to the food (e.g. physical structure and nutrient content) and environmental factors (e.g. availability, family income, cultural origins and tradition). However, in general, these schemes have not attempted to quantify the relative importance of the factors, nor have they elucidated the likely 
mechanisms of action or how the factors might interact. Comprehensive studies of the factors specifically affecting food choice in adolescence are few but some insight is offered by the findings now discussed.

Taste may be a primary determinant of choice in this group. A recent survey directly questioned young people about their most important considerations when deciding what to eat. Taste and quality were found to be primary, whilst cost and health concerns were definitely of secondary importance (Trends in vegetarianism amongst adults and young people; University of Bradford, unpublished results). Williams et al. (1993), in work with Tasmanian school students, found that users of a food tend to like it more than non-users, implying that taste is an important determinant.

In adults, nutrition knowledge has been found to be a predictor of dietary intake, albeit weak (Axelson et al. 1985). In adolescents, however, the picture is less clear. Binns et al. (1981) found that children's good nutrition practices were positively influenced by their nutrition knowledge. In contrast, Chapman \& Maclean (1993) conclude that whilst recent nutrition education efforts have had some success in increasing young people's nutrition knowledge, changes in their eating behaviours have been 'less apparent'. In support, Trexler \& Sargent (1993) found no evidence of a relationship between nutrition knowledge and healthy eating.

Individuals, including adolescents, do not make decisions about foods in a social vacuum and, hence, they are likely to be influenced by those around them. Most work has concentrated on the obvious likely influences of parents and peers. Some reports suggest that parents have a significant influence on their child's diet (Litman et al. 1964; Hertzler \& Vaughan, 1979; Williams et al. 1993). Binns et al. (1981); with older children it was found that the mother was the major influence on the diet, her nutritional knowledge score being related to the child's nutritional practices and knowledge. Parents may act as examples for dietary behaviour, they may determine availability within the household and may offer exposure to different foods. Peers become increasingly important in all areas of social life with increasing age: 'As they become more socially conscious 'going along' with the crowd becomes a must' (Edwards et al. 1964). Khan (1981) reported that social and external considerations, most especially friends, become increasingly significant influences on food choice with transition through adolescence. In contrast, research by Williams et al. (1993) found little relationship between an adolescent's actual food choices and the perceived choices of his or her friends.

Adolescent eating is a major focus for investment by manufacturers and caterers who aim products, eating places and advertising specifically at this sector of the population (Truswell \& Darnton-Hill, 1981). The market for children's foods is worth hundreds of millions of pounds per year and children are bombarded with commercials especially designed to grab and maintain their attention and to make the advertised product highly desirable. Children and adolescents spend a great deal of time watching television and, hence, being exposed to advertisements for food products (Adler et al. 1977). Although the effects of advertising on young children are a cause of controversy (Young, 1990), advertisements are believed by manufacturers and marketers to be highly effective in selling particular products and have been shown in experimental studies to have an influence on food choices of children and adolescents (Aitkin, 1981; Binns et al. 1981; Goldberg, 1990). If nothing else, advertisements provide a picture of the world and what is available which, together with other media, personal knowledge and social interactions, will act as a source of information about social, cultural and sub-cultural norms. 
Prättälä (1989) puts forward some possible reasons for the high preferences among teenagers for what some people would characterize as 'junk foods', suggesting that consumption of these acts as an 'expression of the teenage subculture'. People in this age-group are searching for and developing their own identity and one form of this independence is reflected in the number of meals the adolescent eats away from the home and outside the school environment (Greenwood \& Richardson, 1979). Fast-food outlets are very appealing to young people (Prättälä, 1989). They capitalize on many of the aspects desired by this age-group. They offer a brightly coloured environment, a place to meet friends and where the food is reasonably priced, of consistent quality and the service is 'fast'.

Adolescents, of course do not form a homogeneous group and, hence, within adolescents there are differences between genders, age-groups and socio-economic classes. Generally girls have been found to have lower overall energy intakes, with lower levels of $\mathrm{Fe}, \mathrm{Ca}$, vitamins and other essential nutrients (Bull, 1985, 1988; Department of Health, 1989). Thus, it would appear appropriate to conclude that girls are at greater nutritional risk during adolescence (Truswell \& Darnton-Hill, 1981; Rolls, 1988). Despite these findings, research in Scotland (Anderson et al. 1994) has shown that female adolescents are more likely to be classified as 'healthy eaters' than their male counterparts, with females reporting more frequent consumption of salads and fruit and less frequent consumption of foods high in fat and sugar. Worsley et al. (1984) found significant differences between girls and boys in beliefs about the goodness of foods and preferences even by the age of 10 years. They noted, of interest, that most of these differences were in relation to snack foods, which they hypothesized may act as sex role markers. As adolescents get older so dietary habits change (Topp et al. 1972; Woodward, 1986; Spyckerell et al. 1992), with control over what foods are eaten, where and when increasing significantly with age (Thomas, 1991). However, the effects of age have been found to differ according to sex (Woodward, 1986). Social status has consistently been found to have an influence on a number of features affecting the quality of the adolescent diet. The complexity of a young person's diet was found to be related to the occupational level of their family (Schorr et al. 1972). Fruit consumption (Hackett et al. 1986; Woodward, 1986), use of salt, chips and brown bread (Hackett et al. 1986) and total energy level (Spyckerelle et al. 1992) have also been related to social status. Prättälä (1989), however, concludes that there is no consistent support for linkages between socio-economic class and consumption of foods eaten outside the home.

\section{OBESITY AND DIETING}

One potential consequence of poor nutritional habits in adolescence is the reported increase in the proportions of children and teenagers suffering from obesity (Adamson et al. 1992). It appears, however, that a lack of physical activity may be more important than excess energy intake in teenage obesity (Miller \& Binns, 1979). As a result of their obesity individuals commonly suffer feelings of inferiority, ridicule, failure, dissatisfaction (Worsley, 1981a,b; Furnham et al. 1990) and social rejection and have a greater tendency towards psychological and social problems (Rice, 1978).

However, another cause for concern in relation to the nutritional well-being of adolescents is the prevalence of dieting for weight reduction or weight control. In Western society there is a strong emphasis on physical attractiveness, a defining feature 
of which is slimness (Wardle \& Marsland, 1990). Many adolescents in pursuit of this goal, most especially females (Davis \& Furnham, 1986; Gustafson-Larson \& Terry, 1992), attempt to lose weight by regulating their food intake (Rosen \& Cross, 1987). Reports have found that between 5\% (Bull, 1985; Department of Health, 1989) and 30\% of teenage girls are dieting at any one time (Moses et al. 1989; Patton et al. 1990; Health Education Authority, 1992; Hill et al. 1992).

Several studies have used validated scales of dietary restraint, for example the Dutch Eating Behaviour Scale (van Strien et al. 1986); this provides a measure of the extent to which people are reducing their food consumption in order to control or reduce weight. Responses on this measure show a very consistent pattern; females have considerably and consistently higher scores than males, both for adults (van Strien et al. 1986) and for adolescents (Wardle \& Marsland, 1990; Dennison \& Shepherd, 1995). The scores for 11 year olds have been found to differ little from those of 18 year olds and, indeed, little from the norms found for adults (Wardle \& Marsland, 1990). In girls as young as 9 years old, Hill et al. (1992) found the scores to be approximately the same as those for adult females. Thus, concerns about body weight are becoming evident in children at an increasingly younger age (Wardle \& Beales, 1986; Hill et al. 1989, 1992; Fox et al. 1994). Dieting may be a significant factor influencing the type and amounts of food eaten. Long-term restrictions can have serious consequences for health (Pugliese et al. 1983; Patton et al. 1990) and, according to many, are a precondition for the development of eating disorders (Polivy \& Herman, 1985; Richards et al. 1990).

\section{APPLICATION OF STRUCTURED ATTITUDE MODELS TO ADOLESCENT FOOD CHOICE}

Little of the research on adolescent food choice has adopted a systematic approach. One possibility for examining the role of factors influencing food choice is through the study of beliefs, attitudes and behaviour (Shepherd, 1989). Despite the widespread use in the nutrition literature of the 'knowledge-attitudes-practice' approach, the relationships found between these variables tend to be relatively weak (Axelson et al. 1985), not only in research concerning food choice but also for other forms of behaviour. A more promising approach draws upon the application of social psychological models: Health Belief Model (Becker, 1974), Social Cognitive Theory (Bandura, 1986), Triandis' (1977) model, the Theory of Reasoned Action (TRA; Ajzen \& Fishbein, 1980) and the Theory of Planned Behaviour (TPB; Ajzen, 1991).

The TPB is an attempt to assess the relationship between attitudes and behaviour. It postulates that behaviour is a function of behavioural intention which, in turn, is dependent on three main sets of variables: attitudes towards performing the behaviour, social pressure and, for behaviours which are not under full volitional control, perceptions of control over performing the behaviour. TRA and TPB have been applied across a wide range of behaviours (Ajzen \& Fishbein, 1980; Ajzen, 1991). More recently they have been applied to issues of food choice, e.g. eating in fast-food restaurants (Axelson et al. 1983), choice of infant feeding method (Manstead et al. 1983, 1984), salt consumption (Shepherd \& Farleigh, 1986), eating organic vegetables (Sparks \& Shepherd, 1992) and consuming biscuits and wholemeal bread (Sparks et al. 1992). In general, they show good prediction of intention and behaviour. In a review of studies that used the TRA to assess the determinants of fat and cholesterol intake, Stafleu et al. 
(1991-2) found the attitudinal component to be more important in predicting intentions than is the normative component.

Little research has employed the TRA or TPB in the study of adolescent food choice, the exception being Conner (1992) who applied the TPB to snack-food consumption in schoolchildren. His results revealed the TPB to explain very different amounts of variance in the same behaviour when applying the model to different populations. His conclusion stressed that the addition of other exogenous variables, e.g. moral norms and need for cognition, may improve the predictive power of the model. Dennison \& Shepherd (1995) conducted a study examining the attitudes using a questionnaire based on the TPB. The adolescents were drawn from eight schools (four single sex and four co-educational) from across England, including both males and females, and those aged either 11-12 years or 14-15 years. In all, 675 adolescents completed the questionnaire, which focused on intentions to eat three common foods at lunchtime: chips, fruit and confectionery. Measures of attitudes, subjective norm, perceptions of control over eating and over not eating, dietary restraint, identification of oneself as health conscious and friends' behaviour were included in the questionnaire.

Attitudes and perceived control were the components of the model found to account for the most variance in intentions to eat the foods tomorrow. High levels of perceived control were related to intentions to eat fruit and to the intention not to eat chips or confectionery. The addition of a novel measure of friends' behaviour increased the degree of prediction of intention over and above the basic components of the TPB. The usual wording of the subjective norm component, seeking to measure preceived social pressure, might usefully be replaced by a different form of wording which addresses the issue of peer influence more clearly. Seeing oneself as health conscious (self-identity) was a significant predictor of intentions to eat chips and fruit, with those adolescents who saw themselves as health conscious being less likely to consume chips but more likely to consume fruit. Although within this approach it would be expected that such measures of self-identity might relate to intention and behaviour, this would be expected to act through differences in the beliefs and attitudes held by those with different self-images; similar effects have been found for adult consumption of organic vegetables and people seeing themselves as 'green consumers' (Sparks \& Shepherd, 1992).

Significant age and gender differences in attitudes, beliefs, perceived social pressure and intentions were found. In general, females rated themselves as more health conscious, had more positive beliefs and attitudes about fruit and more negative beliefs and attitudes concerning chips and confectionery. The differences between males and females in their attitudes towards the consumption of chips and confectionery were more marked in the older age-group than in the younger age-group. Females also saw more social pressure to eat fruit and less to eat chips and confectionery than did the males. Thus, females seem to be more concerned about healthy eating and to have more appropriate views on the desirability of eating more fruit and less chips and confectionery, a finding similar to that by Anderson et al. (1994). However, they are also more likely to be restricting their choice and intake of foods for reasons of weight control (Dennison \& Shepherd, 1995).

Effects of socio-economic background and type of school were minimal. This latter point would argue against attitudes to eating being influenced by attending a single sex or a mixed sex school.

In a second study, ninety-six adolescents completed a questionnaire similar to that 
used by Dennison \& Shepherd (1995) on consumption of fruit and chips. The strong contribution of attitudes to the prediction of consumption of both food items was replicated, as was the lack of contribution of the subjective norm. Perceived control significantly improved the prediction of intentions to eat chips. Friends' behaviour was important for intentions to consume fruit (although not chips), an influence that was independent of subjective norm and past behaviour. Past behaviour itself was a significant predictor for both behaviours, most especially for chips. After a period of 2 weeks, eighty of the original group completed the questionnaire for a second time, in order to assess the stability of the measures. Overall, the measures showed relatively high stability over the two measurement occasions. In the intervening week, actual behaviour was measured by observing the pupils at lunchtime in the canteen. Relationships between intentions and behaviour were moderately strong for chips, but not significant for fruit. Problems with the measurement of behaviour may have underestimated the strength of the relationship.

While the previous studies examined the factors influencing adolescent food choice within the highly structured TPB, this does not allow for a more detailed examination of the ways in which the adolescents are thinking about the foods. In a follow-up study, thirty-six in-depth interviews were carried out with young people from the same two age-groups: $11-12$ years and 14-15 years. Questioning focused on a range of topics: what motivates food choice, whether they perceived an influence of friends at lunchtime, what they understood by healthy eating, control factors, influence of advertising, parents, school, etc. Preliminary analysis of the responses suggests that many individuals, especially those in the older age-group, are aware of and able to describe the influence of peers upon them. There are definite 'norms' for what to eat, and though unwilling to admit that they themselves are influenced by their friends, they still held the view that many others are directly influenced by what their friends are having. Any mention of 'copying' was rebuked. However, many were able to talk about the effects of nonconformity. There was recurrent reference to 'adult' $v$. 'kids' food. Most claimed they were in control of what they are eating at school, although the amount of money they had to spend had an influence. At home, their own control was reported to be lower, with parents and availability of foods being more influential. The major reason given for choices was liking; often the meal that they were intending to have was also their favourite meal. Health was usually not cited as a consideration. Orientation was very definitely towards the here and now. For males, involvement in sport was not seen to be related to diet. Advertising was pinpointed as having an influence on choice, although many were unwilling to say that information presented in the canteen had any effect. Parents were seen as wanting their children to eat more healthily; however, this was often reported to be ignored.

Findings from these studies are currently being implemented in a short intervention study. Attempts to manipulate the influence of peers on food choice is a focus in this intervention. Groups of friends who regularly eat together will be encouraged to set goals to increase their consumption of fruit and vegetables and decrease their intake of chips. The accent will be placed on using peers as a source of support for healthy eating intentions. In addition the quality and range of fruit and vegetable provision within the canteen will be increased. The importance of this environmental manipulation will be assessed independent of, and in conjunction with, the setting of goals and peer influence. 
The intervention will be evaluated by means of $4 \mathrm{~d}$ diet diaries and a questionnaire addressing attitudes and beliefs; change over a period of 1 month will be monitored.

\section{CONCLUSIONS}

There is a need to understand the dietary behaviour of adolescents if dietary habits are to be improved. Adolescence is a time of changes, both biological and social, and hence offers an excellent opportunity for exploring the factors influencing food choice. However, relatively little work has addressed the reasons for dietary choices in this group. Issues of importance are the influence of peer 'pressure' on food choices and the degree of control which the adolescents feel they have over the choices they make. The persistence of dietary habits acquired in adolescence needs to be assessed in order to see whether this has long-term implications for diet and health.

The authors would like to thank Fairfield Catering Company for funding work described in this paper and Niamh Rice and Maggie Price for their help and support in carrying out parts of the research described.

\section{REFERENCES}

Adamson, A., Rugg-Gunn, A. J., Butler, T., Appleton, D. R. \& Hackett, A. (1992). Nutritional intake, height and weight of 11-12-year-old Northumbrian children in 1990 compared with information obtained in 1980. British Journal of Nutrition 68, 543-563.

Adler, R. P., Friedlander, B. Z., Lesser, G. S., Meringoff, L., Robertson, T., Rossiter, J. R. \& Ward, S. (1977). Research on the Effects of Television Advertising on Children: A Review of the Literature and Recommendations for Future Research. Washington, DC: US Government Printing Office.

Aitkin, C. K. (1981). Effects of television advertising on children. In Children and the Faces of Television: Teaching, Violence and Selling, pp. 287-304 [E. L. Palmer and A. Dorr, editors]. New York: Academic Press.

Ajzen, I. (1991). The theory of planned behavior. Organizational Behavior and Human Decision Processes 50, $179-211$.

Ajzen, I. \& Fishbein, M. (1980). Understanding Attitudes and Predicting Social Behavior. Englewood Cliffs, NJ: Prentice-Hall.

Anderson, A. S., Sweeting, H. \& West, P. (1994). Longitudinal changes in the snack food choices of teenagers living in the west of Scotland. Proceedings of the Nutrition Society 53, $100 \mathrm{~A}$.

Axelson, M. L., Brinberg, D. \& Durand, J. H. (1983). Eating at a fast-food restaurant - A social-psychological analysis. Journal of Nutrition Education 15, 94-98.

Axelson, M. L., Federline, T. L. \& Brinberg, D. (1985). A meta-analysis of food and nutrition related research. Journal of Nutrition Education 17, 51-54.

Bandura, A. (1986). Social Foundations of Thought and Action. Englewood Cliffs, NJ: Prentice-Hall.

Becker, M. (1974). The health belief model and sick role behavior. Health Education Monographs 2, 401-419.

Bigler-Doughten, S. \& Jenkins, R. M. (1987). Adolescent snacks, nutrient density and nutritional contribution to total intake. Journal of the American Dietetic Association 87, 1678-1679.

Binns, C. W., Caffin, N. A. \& Miller, M. R. (1981). Determinants of children's eating practices. Proceedings of the Nutrition Society of Australia $6,167$.

Birch, L. L. (1987). Children's food preferences: developmental patterns and environmental influences. Annals of Child Development 4, 171-208.

Booth, D. A. \& Shepherd, R. (1988). Sensory influences on food acceptance: the neglected approach to nutrition promotion. British Nutrition Foundation Nutrition Bulletin 13, 39-54.

Bull, N. L. (1985). Dietary habits of 15-25 year olds. Human Nutrition: Applied Nutrition 39A, Suppl. 1, 1-68.

Bull, N. L. (1988). Studies of the dietary habits, food consumption and nutrient intakes of adolescents and young adults. World Review of Nutrition and Dietetics 57, 24-74. 
Chapman, G. \& Maclean, H. (1993). 'Junk food' and 'healthy food': meanings of food in adolescent women's culture. Journal of Nutrition Education 25, 108-113.

Coleman, J. C. \& Hendry, L. (1990). The Nature of Adolescence, 2nd ed. London: Routledge.

Conner, M. T. (1992). Individualised measurement of attitudes toward foods. Presented at Food Choice Conference, Brussels.

Crawley, H. (1993). Nutrient and food intakes of teenagers aged 16-17 years in Britain. 2. Energy, macronutrients and non-starch polysaccharides. British Journal of Nutrition 70, 15-26.

Davis, E. \& Furnham, A. (1986). The dieting and body shape concerns of adolescent females. Journal of Child Psychology and Psychiatry 27, 417-428.

Dennison, C. M. \& Shepherd, R. (1995). Adolescent food choice: an application of the Theory of Planned Behaviour. Journal of Human Nutrition and Dietetics 8, 9-23.

Department of Health (1989). The Diets of British Schoolchildren. Committee on Medical Aspects of Food Policy. Report on Health and Social Subjects no. 36. London: H.M. Stationery Office.

Edwards, C. H., Morgan, G., Spahr, S. \& Guilford County Nutrition Committee (1964). Implications for nutrition education: nutrition survey of 6200 teenage youths. Journal of the American Dietetic Association 45, 543-546.

Fox, K. R., Page, A., Peters, D. M., Armstrong, N. \& Kirby, B. (1994). Dietary restraint and fatness in early adolescent girls and boys. Journal of Adolescence 17, 149.

Furnham, A., Hester, C. \& Weir, C. (1990). Sex differences in the preference for specific female body shapes. Sex Roles 22, 743.

Goldberg, M. E. (1990). A quasi-experiment assessing the effectiveness of TV advertising directed to children. Journal of Marketing Research 27, 445-454.

Golding, J., Haslum, M. \& Morris, A. (1984). Eating habits of ten year olds. Nutrition and Food Science 57, 178-179.

Greenwood, C. T. \& Richardson, D. P. (1979). Nutrition during adolescence. World Review of Nutrition and Dietetics 33, 1-41.

Greger, J. L., Divilbiss, L. \& Aschenbeck, S. K. (1979). Dietary habits of adolescent females. Ecology of Food and Nutrition 7, 213-218.

Gustafson-Larson, A. \& Terry, R. D. (1992). Weight-related behaviors and concerns of fourth grade children. Journal of the American Dietetic Association 92, 818-822.

Hackett, A. F., Rugg-Gunn, A. J., Appleton, D. R. \& Coombs, A. (1986). Dietary sources of energy, protein, fat and fibre in 375 English adolescents. Human Nutrition: Applied Nutrition 40A, 176-184.

Hampton, M. C., Huenemann, R. L., Shapiro, L. R. \& Mitchell, B. W. (1967). Caloric and nutrient intakes of teen-agers. Journal of the American Dietetic Association 50, 385-396.

Health Education Authority (1992). Today's Young Adults. 16-19 Year Olds Look at Diet, Alcohol, Drugs and Sexual Behaviour. London: HEA.

Hertzler, A. A. \& Vaughan, C. E. (1979). The relationship of family structure and interaction to nutrition. Journal of the American Dietetic Association 74, 23-27.

Hill, A. J., Oliver, S. \& Rogers, P. J. (1992). Eating in the adult world: the rise of dieting in childhood and adolescence. British Journal of Clinical Psychology 31, 95-105.

Hill, A. J., Rogers, P. J. \& Blundell, J. (1989). Dietary restraint in young adolescent girls: a functional analysis. British Journal of Clinical Psychology 28, 165-176.

Huenemann, R. L., Shapiro, L. R., Hampton, M. C. \& Mitchell, B. W. (1968). Food and eating practices of teen-agers. Journal of the American Dietetic Association 53, 17-24.

Jackson, S. (1993). Social behaviour in adolescence: the analysis of social interaction sequences. In Adolescence and its Social Worlds, pp. 15-45 [S. Jackson and H. Rodriquez-Tome, editors]. Hove, Sussex: Lawrence Erlbaum Associates.

Jackson, S. \& Bosma, H. A. (1992). Developmental research on adolescence: European perspectives for the 1990s and beyond. British Journal of Developmental Psychology 10, 319-337.

Khan, M. A. (1981). Evaluation of food selection patterns and preferences. CRC Critical Reviews in Food Science and Nutrition 15, 129-153.

Krondl, M. \& Lau, D. (1982). Social determinants in human food selection. In The Psychobiology of Human Food Selection, pp. 139-151 [L. M. Barker, editor]. Chichester: Ellis Horwood.

Litman, T., Cooney, J. \& Stief, R. (1964). The views of Minnesota school children on food. Journal of the American Dietetic Association 45, 433-440.

Manstead, A. S. R., Plevin, C. E. \& Smart, J. L. (1984). Predicting mothers' choice of infant feeding method. British Journal of Social Psychology 23, 223-231. 
Manstead, A. S. R., Proffitt, C. \& Smart, J. L. (1983). Predicting and understanding mothers' infant-feeding intentions and behavior: testing the theory of reasoned action. Journal of Personality and Social Psychology 44, 657-671.

Miller, M. R. \& Binns, C. W. (1979). Cultural differences in children's TV viewing habits and implications for nutritional status. Proceedings of the Nutrition Society of Australia 4, 120.

Moses, N., Banilivy, M. M. \& Lifschitz, F. (1989). Fear of obesity among adolescent girls. Pediatrics 83, 393-398.

Nelson, M. (1982). Dietary practices of adolescents. Current Concepts in Nutrition 11, 35-44.

Noller, P. \& Callan, V. (1991). The Adolescent in the Family. London: Routledge.

Patton, G. C., Johnson-Sabine, E., Wood, K., Mann, A. H. \& Wakeling, A. (1990). Abnormal eating attitudes in London schoolgirls - a prospective epidemiological study, outcome at twelve month follow up. Psychological Medicine 20, 383-394.

Pilgrim, F. J. (1957). The components of food acceptance and their measurement. American Journal of Clinical Nutrition 5, 171-175.

Polivy, J. \& Herman, P. (1985). Dieting and binging. American Psychologist 40, 193-201.

Post, B., Kemper, H. \& Storm-van Essen, L. (1986). Snacking habits in Dutch adolescents. International Journal of Eating Disorders 5, 85-100.

Prättälä, R. (1989). Young people and food: socio-cultural studies of food consumption patterns. Doctoral Thesis, University of Helsinki, Finland.

Pugliese, M. T., Lifschitz, F., Grad, G., Fort, P. \& Marks-Katz, M. (1983). Fear of obesity: a cause of short stature and delayed puberty. New England Journal of Medicine 309, 513-518.

Randall, E. \& Sanjur, D. (1981). Food preferences - their conceptualization and relationship to consumption. Ecology of Food and Nutrition 11, 151-161.

Rice, F. P. (1978). The Adolescent: Development, Relationships and Culture. Boston: Allyn and Bacon.

Richards, M., Casper, R. \& Larson, R. (1990). Weight and eating concerns among pre- and young adolescent boys and girls. Journal of Adolescent Health Care 11, 203-209.

Roberton, D. J. (1981). The school meal service - a new responsibility for the food manufacturer. Food Trade Review July, 351-352.

Rolls, B. J. (1988). Food beliefs and food choices in adolescents. Medical Journal of Australia 148, 9-13.

Rose, R. \& Falconer, P. (1992). Individual taste or collective decision? Public policy on school meals. Journal of Social Policy 21, 349-373.

Rosen, J. C. \& Gross, J. (1987). Prevalence of weight reducing and weight gaining in adolescent girls and boys. Health Psychology 6, 131-147.

Schorr, B. C., Sanjur, D. \& Erikson, E. (1972). Teen-age food habits. Journal of the American Dietetic Association 61, 415-420.

Shepherd, R. (1985). Dietary salt intake. Nutrition and Food Science 96, 10-11.

Shepherd, R. (editor) (1989). Factors affecting food preferences and choice. In Handbook of the Psychophysiology of Human Eating, pp. 3-24. Chichester: Wiley.

Shepherd, R. \& Farleigh, C. A. (1986). Attitudes and personality related to salt intake. Appetite 7, 343-354.

Simmons, R. G., Burgeson, R., Carlton-Ford, S. \& Blyth, D. (1987). The impact of cumulative change in early adolescence. Child Development 58, 1220-1234.

Sparks, P., Hedderley, D. \& Shepherd, R. (1992). An investigation into the relationship between perceived control, attitude variability and the consumption of two common foods. European Journal of Social Psychology 22, 55-71.

Sparks, P. \& Shepherd, R. (1992). Self-identity and the theory of planned behavior: assessing the role of identification with 'green consumerism'. Social Psychology Quarterly 55, 388-399.

Spyckerelle, Y., Herbeth, B. \& Deschamps, J. (1992). Dietary behaviour of an adolescent French male population. Journal of Human Nutrition and Dietetics 5, 161-168.

Stafleu, A., de Graaf, C., van Staveren, W. A. \& Schroots, J. J. F. (1991-2). A review of selected studies assessing social psychological determinants of fat and cholesterol intake. Food Quality and Preference 3, $183-200$.

Stare, F. \& Dwyer, J. (1969). An eye to the future: healthy eating for teenagers. Journal of School Health 3, 595-599.

Thomas, J. (1991). Food choices and preferences of schoolchildren. Proceedings of the Nutrition Society 50, 49-57.

Thomas, J. A. \& Call, D. L. (1973). Eating between meals - a nutrition problem among teenagers. Nutrition Reviews 31, 137-139. 
Topp, S. G., Cook, J. \& Elliott, A. (1972). Measurement of nutritional intake among school children. British Journal of Preventative Social Medicine 26, 106.

Trexler, M. L. \& Sargent, R. (1993). Assessment of nutrition risk knowledge and its relationship to the dietary practices of adolescents. Journal of Nutrition Education 25, 337-344.

Triandis, H. C. (1977). Interpersonal Behavior. Monterey, CA: Brooks/Cole.

Truswell, A. S. \& Darnton-Hill, I. (1981). Food habits of adolescents. Nutrition Reviews 39, 73-88.

van Strien, T., Frijters, J. E. R., Bergers, G. P. A. \& Defares, P. B. (1986). The Dutch Eating Behavior Questionnaire (DEBQ) for assessment of restrained, emotional, and external eating behavior. International Journal of Eating Disorders 5, 295-315.

Wardle, J. \& Beales, S. (1986). Restraint, body image and food attitudes in children from 12 to 18 years. Appetite 7, 209-217.

Wardle, J. \& Marsland, L. (1990). Adolescent concerns about weight and eating: a social developmental perspective. Journal of Psychosomatic Research 34, 377-391.

Williams, H. M., Woodward, D. R., Ball, P. J., Cumming, F. J., Hornsby, H. \& Boon, J. A. (1993), Food perceptions and food consumption among Tasmanian high school students. Australian Journal of Nutrition and Dietetics 50, 156-163.

Woodward, D. R. (1986). What influences adolescent food intakes? Human Nutrition: Applied Nutrition 40A, 185-194.

Worsley, A. (1981a). Teenagers' perceptions of fat and slim people. International Journal of Obesity 5 , $170-179$.

Worsley, A. (1981b). In the eye of the beholder: social and personal characteristics of teenagers and their impressions of themselves and fat and slim people. British Journal of Medical Psychology 54, 231-242.

Worsley, A., Baghurst, P., Worsley, A. J., Coonan, W. \& Peters, M. (1984). Australian ten year olds' perceptions of food: sex differences. Ecology of Food and Nutrition 15, 231-246.

Young, B. M. (1990). Television Advertising and Children. Oxford: Clarendon Press.

Yudkin, J. (1956). Man's choice of food. Lancet i, 645-649. 